Article

\title{
The Right Amount of Technology in School Buildings
}

\author{
Thomas Auer, Philipp Vohlidka * and Christine Zettelmeier
}

Chair for Building Technology and Climate Responsive Design, Faculty of Architecture, Technische Universität München, 80333 Munich, Germany; thomas.auer@tum.de (T.A.); christine.zettelmeier@tum.de (C.Z.)

* Correspondence: philipp.vohlidka@tum.de; Tel.: +49-89-289-22585

Received: 13 November 2019; Accepted: 2 February 2020; Published: 5 February 2020

check for updates

\begin{abstract}
What is an adequate school building nowadays and which amount of technology does it need? How high is the indoor comfort in terms of thermal, visual, hygienic, and acoustical comfort? Are there technical aspects that stand out to other solutions? How do users feel and act in the buildings? For this purpose, the Chair compared, in total, twelve selected modern, older, and renovated school buildings from different building age groups. For the comparison, it was essential to intensively analyze each of the twelve schools. This included visiting the schools, talking with the participating architects, specialist planners, builders, and school managers, procuring and analyzing planning documents and, where available, publications and reports, performing simulations and measurements in the classrooms, and surveying the buildings' users. The predominant energy demand in schools is the energy expenditure for heating and cooling the air, especially for heating the air in the winter. Nevertheless, it turns out that from a purely energy-focused perspective, mechanical ventilation cannot be justified. It is also evident that transmission heat losses play a negligible role in school construction, which is why the "passive house" as a goal for renovations must be called into question.
\end{abstract}

Keywords: schools; education; technology; comparison; comfort; indoor quality; evaluation; analysis

\section{Introduction}

The schoolhouse typology changed from a one-room country school to a vivid complex special structure [1] and is no longer defined as just a building where knowledge is conveyed. Rather, it is a place that invites learning, teaching, playing, communicating, and spending time, and that users associate with certain emotions and life stages. At the Technical University of Munich, the Chair of Building Technology and Climate Responsive Design, Prof. Thomas Auer, has been pursuing the question of what constitutes an adequate school building in terms of technology today.

For this purpose, the Chair intensively compared twelve school buildings (Figure 1) in three different countries. They range from an elementary school on Haimhauserstraße in Munich that is over 100 years old, to a school from the 1970s that was renovated into a passive house, to the Schmuttertal-Gymnasium in Diedorf, which fulfills the "zero-energy building standard" and which has already received countless awards. 


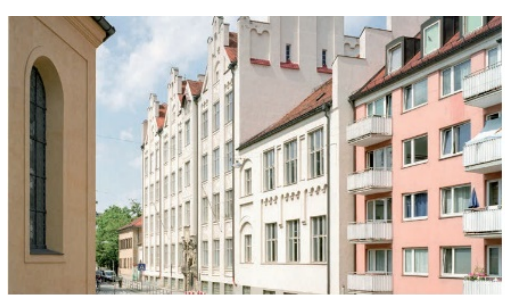

Grundschule an der Haimhauserstraße, Munich, 1898
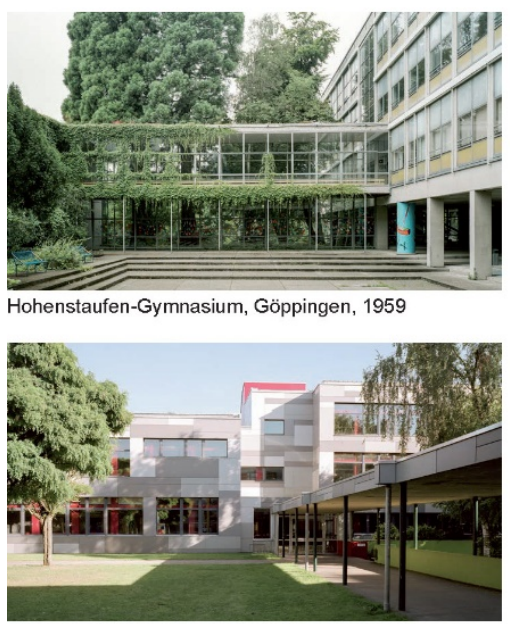

Gymnasium Baesweiler, 1978

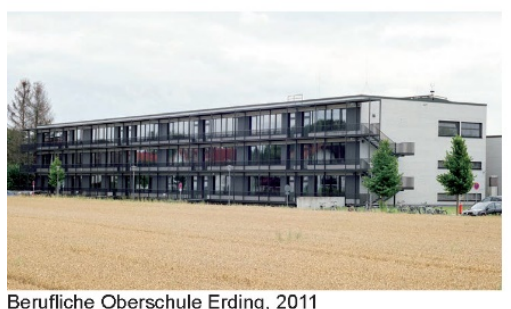

Berufliche Oberschule Erding, 2011

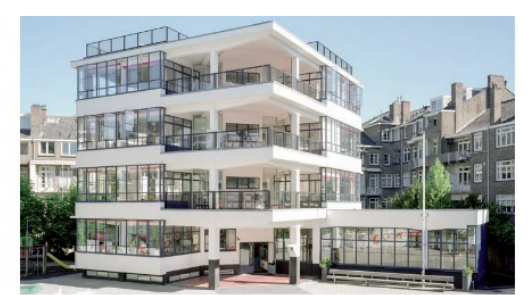

Erste Openluchtschool, Amsterdam, 1931

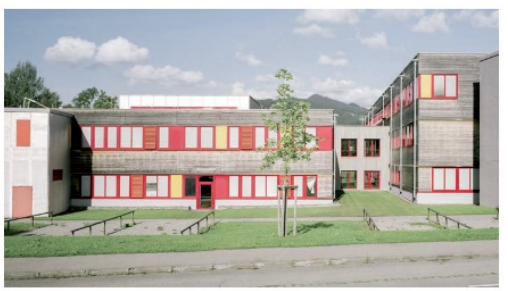

Gymnasium Sonthofen, 1976

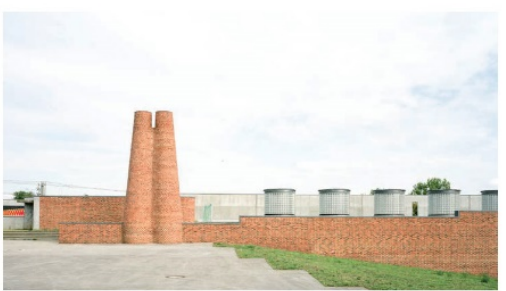

Schule im Park, Ostfilldern, 1999

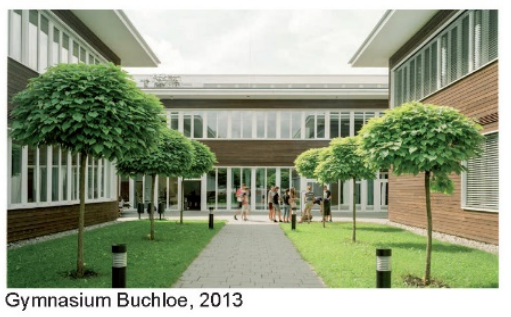

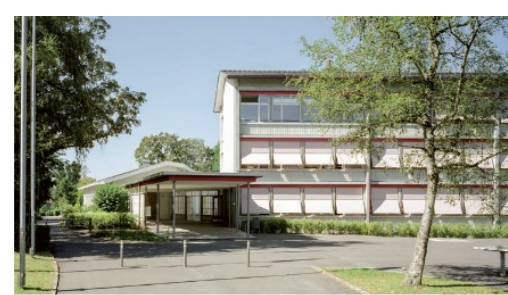

Schulanlage Wandermatte, Wabern, 1956

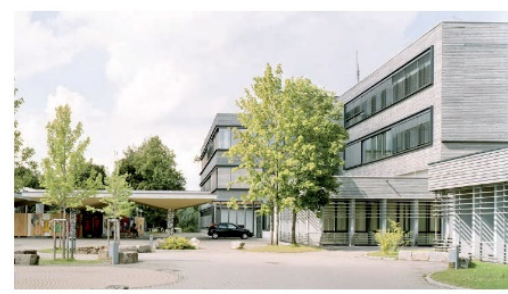

Mittelschule Buchloe, 1976

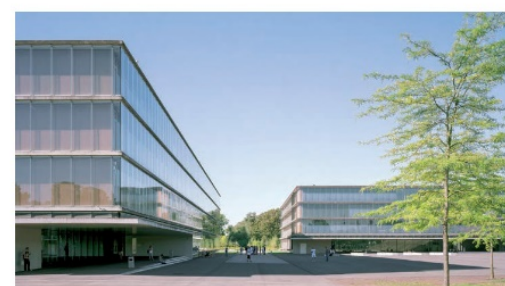

Max-Born-Berufskolleg, Recklinghausen, 2008

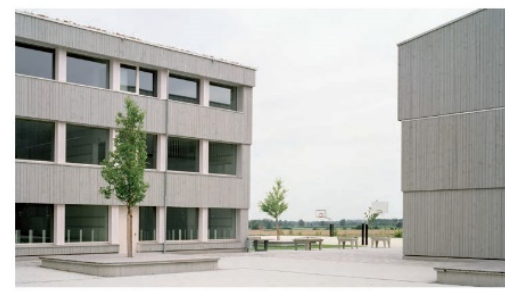

Schmuttertal Gymnasium, Diedorf, 2015

Figure 1. Schools from the outside.

Indoor environmental quality mainly depends on thermal, hygienic, visual, and acoustical comfort [2]. To investigate these criteria in the selected school buildings, short- and long-term measurements were conducted in two exemplary classrooms of each building and complemented by dynamic modeling. Through a survey, we compared the results with the building users' subjective perception of the indoor environmental quality. Additionally, the active and passive systems of each school building were analyzed in terms of their efficiency and their interdependence among one another.

We investigated how much energy the buildings' active systems need to fulfil the previously detected comfort parameters, identify the biggest energy consumers in the buildings, and demonstrate under which circumstances it is reasonable to save energy. Of particular interest was the overriding question of if sustainable architecture necessarily leads to more technology. Sustainable architecture nowadays often refers to buildings which are highly technically equipped [3] and thus, only controllable by the help of expert knowledge or to passive house schools in which the users are deprived of ventilating naturally by simply opening the windows. In order to critically question such concepts, schools with significantly different technical standards were compared within this study. The results of the study demonstrate what positive solutions look like, but also how problems can arise.

\section{Materials and Methods}

We used a variety of different methods to analyze the different school buildings. Figure 2 shows the research flow diagram. The subsequent text describes the applied methodologies in detail. 


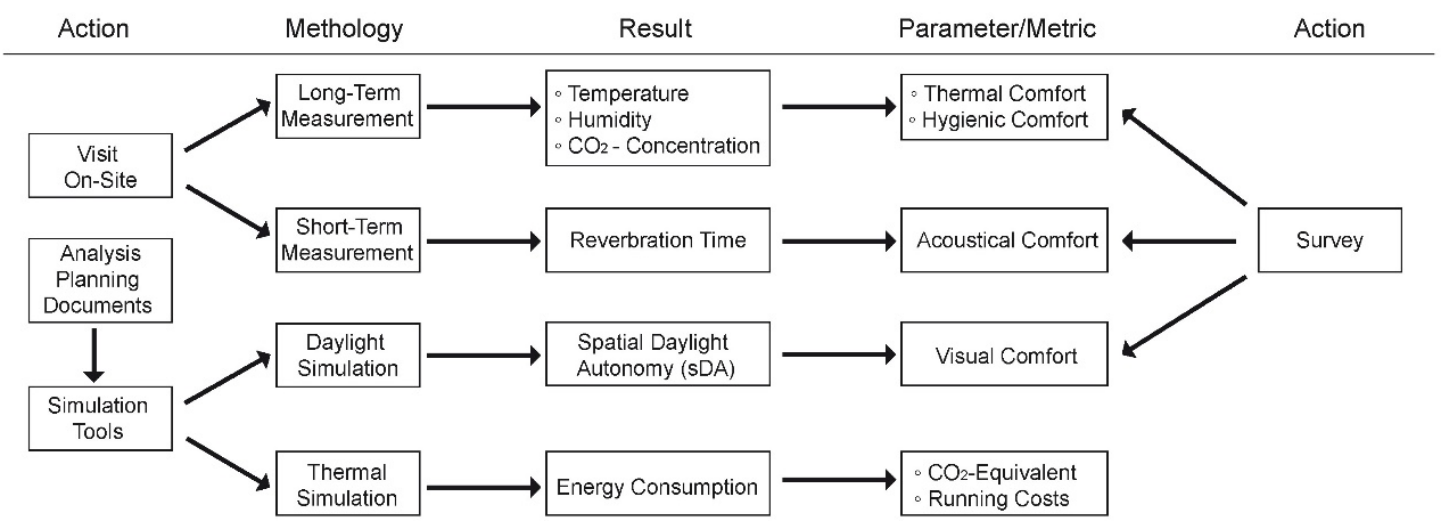

Figure 2. Research flow diagram.

\subsection{Measurement Methodology}

Using different measurements, we examined the twelve schools in order to compare the comfort parameters. In each school, we chose two exemplary classrooms with identical orientations and volumes. To measure the classrooms' long-term thermal and hygienic comfort, we used instruments from the manufacturer IC-Meter, that recorded, in 5-minute intervals, indoor air temperature, humidity, $\mathrm{CO}_{2}$ concentration, and the sound level. In addition, they collected data about the outside air temperature from the nearest weather station. Although the measurement period for each of the schools studied is not identical, we were careful to collect data over several months from both cold and warm seasons in 2016. The sensors were mounted on the inner wall opposite the facade side at a measuring height of $1.2 \mathrm{~m}$. It was possible to determine the periods of use by means of the recorded sound level data, which provided information about room occupancy. The included scatter plots in Figures 5,7,8 show five-minute values exclusively during the periods of occupancy. The $\mathrm{CO}_{2}$ concentration should provide objective information about the air quality, but it only serves as an indicator for other air contaminants: odors or volatile organic compounds, so-called VOCs, cannot be detected, or only with great difficulty. The $\mathrm{CO}_{2}$ concentrations typically measured indoors are not dangerous to humans, but they do correlate with the subjective perception of "stuffy, stale" air. To represent this, we use two graphics (Figures 5 and 6). The cumulative probability indicates the minimum $\mathrm{CO}_{2}$ concentration. The two lines indicate outside air temperatures above and below $12{ }^{\circ} \mathrm{C}$. This distinction is based on the assumption that users no longer manually open the windows when it is below $12{ }^{\circ} \mathrm{C}$, due to draught. The second graph shows the $\mathrm{CO}_{2}$ concentration in relation to the outside air temperature. You can also see the four categories of recommended limit values according to the German standard for ventilation of non-residential buildings DIN EN 13779 [4].

Category I is up to $400 \mathrm{ppm}$ above the outdoor $\mathrm{CO}_{2}$ concentration, which is uniformly set at $400 \mathrm{ppm}$ in all schools. Category II is up to $600 \mathrm{ppm}$ above the outdoor concentration, Category III is up to 1000 ppm above, and Category IV is greater than 1000 ppm above.

Air temperature and humidity provide information about thermal comfort. The radiant temperature (the average surface temperature of the enclosure surfaces) was disregarded. The mean of the ambient air temperature and radiant temperature gives the so-called operative temperature, which corresponds to what people perceive. Determining the radiant temperature would be very complex, and in any case, the difference between the air and radiant temperatures in the well-insulated schools is relatively low. This slight vagueness is, however, within an acceptable range because a proper consideration of the operative temperature would not change the evidence of the investigations. A complex determination of the radiant temperature would thus provide no additional knowledge in the context of our investigations. Two different graphs display thermal comfort: the first (Figure 7) shows the indoor air temperatures and presents these in relation to the prevailing outside air temperatures. The area between the lines is the recommended range of indoor air temperature, which increases to a certain extent as the outside air temperature increases. This area is based on the DIN EN 15251 [5], even 
though, in this case, what is shown is not the operative air temperature, but the indoor air temperature we measured. In Figure 8, the second graph shows the indoor air temperature in relation to indoor air humidity. The recommended comfort range according to DIN 1946-6 [6] is between the grey lines. Here, the recommended temperature is independent of the outside air temperature between 20 and 26 ${ }^{\circ} \mathrm{C}$. By definition, the relative humidity should ideally be between $30 \%$ and $65 \%$ and should not exceed the absolute humidity value of $11.5 \mathrm{~g} / \mathrm{kg}$. Using the software program AkuCheck from the University of Wuppertal, we determined the reverberation time in each classroom. This provides information about speech intelligibility, which is particularly important in school construction. The recommended reverberation times at different frequencies, according to DIN 18041 [7], depend on the volume of the classroom and therefore differ slightly from one school to another. Since we carried out the measurements in unoccupied rooms, we virtually added an occupancy of 25 people in the software. In the graphs, the determined reverberation time is represented by the black line and the gray area represents the recommended reverberation time.

\subsection{Simulation Methodology}

To evaluate and compare energy consumption, we originally planned to obtain information on electricity and heat consumption from all schools. During the course of the work, however, it turned out that the meter information is not comparable in terms of energy consumption. For example, our sample included all-day schools, as well as schools such as the Gymnasium Buchloe, which have a school kitchen with a canteen, and technologically oriented schools such as the Max-Born- Berufskolleg, where many of the teaching activities consume significant amounts of electricity. In order to be able to directly compare energy performance, we decided to thermally simulate the twelve schools under standardized boundary conditions using the building simulation software, TRNSYS version 17. It was a matter of determining which parameter is most suitable for comparing energy consumption in the "fairest" way possible. Above all, we wanted to make the structural qualities transparent rather than focus on technical parameters such as the efficiency of the municipality's district heating supply.

Useful energy is principally a matter of structural quality, but it does not take into account the type of heating/cooling system or the power consumption of the system technology. A consideration of the end energy, in turn, would lead to a distorted picture for all buildings that use heat pumps for heating and cooling. As shown in Figure 3, we redefined the system boundary and introduced the concept of "space energy demand". This includes the values for heating, cooling, auxiliary energy, and artificial light in $\mathrm{kWh} / \mathrm{m}^{2}$ a. It simulates a classroom located on the top floor with the appropriate buildings components and building services systems, such as the heating/cooling system, while taking into account all the external energy consumers, such as the ventilation system.

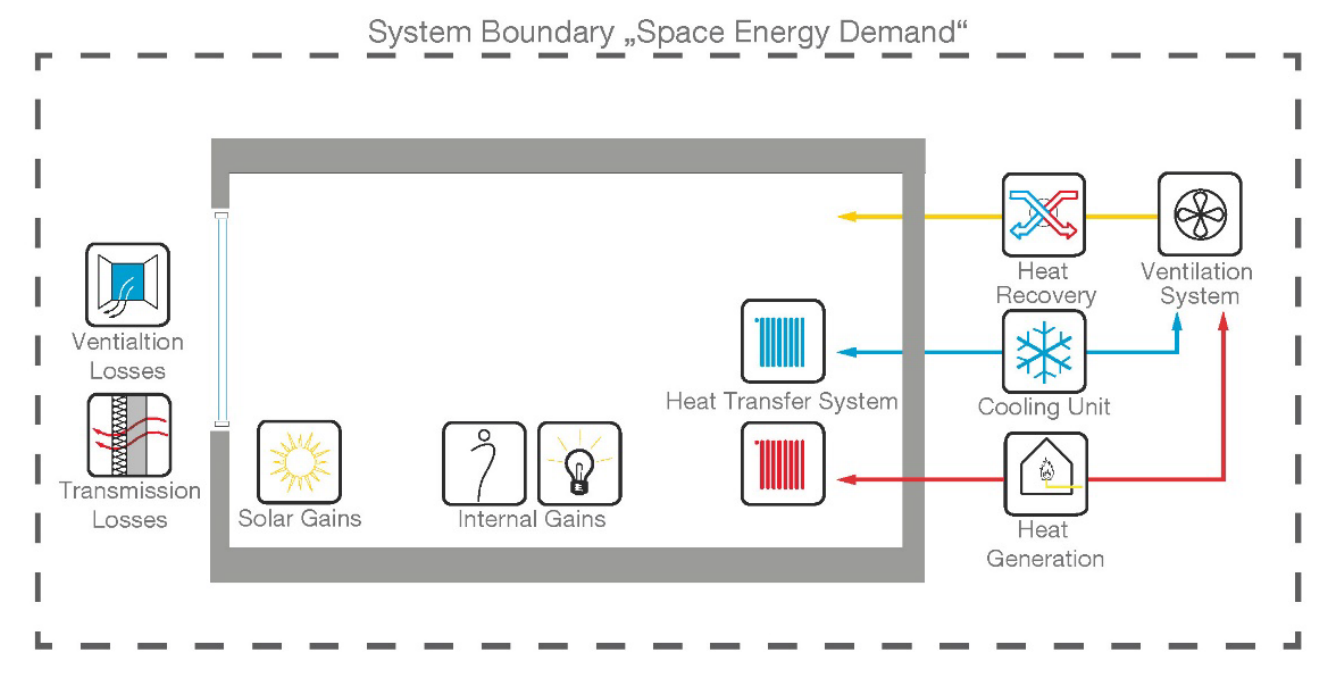

Figure 3. Definition of the system boundary "space energy demand". 
Table 1 shows an overview of the technical equipment of the schools. With this simulation, it is possible to work out structural and technical differences and, at the same time, to standardize user influences such as teaching times. To do this, we assumed both an ideal user and optimal measurement, control, and regulation technology (MCR), in accordance with the planner's specifications. For example, we assumed that the user will open the window if the $\mathrm{CO}_{2}$ concentration is higher than $1400 \mathrm{ppm}$, even if this does not coincide with reality. Thus, naturally ventilated schools perform poorer at heating the space in the simulation than in reality because in the simulation, more heat is needed to warm all the fresh air. We also use an "ideal user" when calculating the electricity demand of artificial lighting. This ideal user only switches on artificial light when it is necessary. In reality, the electricity demand for artificial lighting is certainly higher, but this assumption makes it possible to compare the schools.

Table 1. Technical overview.

\begin{tabular}{|c|c|c|c|c|c|}
\hline Name of the School & Heating & Cooling & Heat Transfer & Ventilation & $\begin{array}{l}\text { Sun/Glare } \\
\text { Protection }\end{array}$ \\
\hline $\begin{array}{l}\text { Grundschule } \\
\text { an der } \\
\text { Haimhauserstr. }\end{array}$ & Gas Boiler & - & Radiator & Windows & Curtains-Inside \\
\hline $\begin{array}{l}\text { Eerste Openlucht- } \\
\text { school }\end{array}$ & $\begin{array}{l}\text { Gas Condensing } \\
\text { Boiler }\end{array}$ & Compressor & Flat Radiator & $\begin{array}{l}\text { Centralized } \\
\text { Mechanical } \\
\text { Ventilation }\end{array}$ & Textile-Inside \\
\hline $\begin{array}{l}\text { Schulanlage } \\
\text { Wandermatte }\end{array}$ & Wooden Pellets & - & Radiator & Windows & Louvers-External \\
\hline $\begin{array}{l}\text { Hohenstaufen- } \\
\text { Gymnasium }\end{array}$ & District Heating & - & Radiator & Windows & Louvers-External \\
\hline $\begin{array}{l}\text { Gymnasium } \\
\text { Sonthofen }\end{array}$ & $\begin{array}{l}\text { - Ground Water with } \\
\text { Heat Pump } \\
\text { - Co-Generation } \\
\text { - Gas Condensing } \\
\text { Boiler }\end{array}$ & Ground Water & $\begin{array}{l}\text { Radiant Ceiling } \\
\text { Panels }\end{array}$ & $\begin{array}{l}\text { Centralized } \\
\text { Mechanical } \\
\text { Ventilation }\end{array}$ & $\begin{array}{l}\text { Louvers between } \\
\text { Window Glass }\end{array}$ \\
\hline Mittelschule Buchloe & District Heating & - & Air Heating & $\begin{array}{l}\text { Centralized } \\
\text { Mechanical } \\
\text { Ventilation }\end{array}$ & Louvers-External \\
\hline $\begin{array}{l}\text { Gymnasium der } \\
\text { Stadt Baesweiler }\end{array}$ & $\begin{array}{l}\text { - Boreholes with } \\
\text { Heat Pump } \\
\text { - Gas Condensing } \\
\text { Boiler }\end{array}$ & - & $\begin{array}{l}\text { Radiant Ceiling } \\
\text { Panels }\end{array}$ & $\begin{array}{l}\text { Centralized } \\
\text { Mechanical } \\
\text { Ventilation }\end{array}$ & Louvers-External \\
\hline Schule im Park & District Heating & - & Radiator & Windows & Textile-External \\
\hline Max-Born-Berufskolleg & Co-Generation & $\begin{array}{l}\text { Compressor } \\
\text { Boreholes }\end{array}$ & $\begin{array}{c}\text { Air-Flow-based } \\
\text { TAB } \\
\text { Convector }\end{array}$ & $\begin{array}{l}\text { Centralized } \\
\text { Mechanical } \\
\text { Ventilation }\end{array}$ & Louvers-External \\
\hline $\begin{array}{c}\text { Berufliche } \\
\text { Oberschule Erding }\end{array}$ & District Heating & Ground Water & $\begin{array}{l}\text { Wall Radiant } \\
\text { Heating }\end{array}$ & $\begin{array}{l}\text { Centralized } \\
\text { Mechanical } \\
\text { Ventilation }\end{array}$ & Louvers-External \\
\hline Gymnasium Buchloe & $\begin{array}{c}\text { Ground Water with } \\
\text { Heat Pump. } \\
\text { Solar Thermal }\end{array}$ & Ground Water & $\begin{array}{l}\text { Radiant Ceiling } \\
\text { Panels }\end{array}$ & $\begin{array}{l}\text { Decentral. } \\
\text { Mechanical } \\
\text { Ventilation }\end{array}$ & Louvers-External \\
\hline Schmuttertal-Gymnasium & n Wooden Pellets & $\begin{array}{l}\text { Compressor. } \\
\text { Adabatic } \\
\text { Cooling }\end{array}$ & Floor Heating & $\begin{array}{l}\text { Centralized } \\
\text { Mechanical } \\
\text { Ventilation }\end{array}$ & Louvers-External \\
\hline
\end{tabular}

Winter thermal comfort was uniformly set to a minimum operating room temperature of $20^{\circ} \mathrm{C}$. The thermal comfort in the summer was not standardized but simulated in accordance with the realized system settings. The heating and cooling systems, including how they are regulated, are also represented in the simulation according to the planner's specifications. In order to determine the efficiency of the energy supply systems, we used uniform parameters. 
In order to include an evaluation of the energy sources, it is possible to account for either the primary energy or the $\mathrm{CO}_{2}$ emissions. Looking at the primary energy gives a distorted picture in the schools that are connected to district heating, because district heating networks often employ waste incineration, which leads to very good primary energy factors. This is why we decided to account for the $\mathrm{CO}_{2}$ equivalent (Table 2). The factors come from the GEMIS database (Global Emission Model for integrated Systems), version 4.93 [8]. For schools that are connected to a heating network, we either collected the values directly from the heating companies or determined them on the basis of the data provided by the municipal utilities themselves. Photovoltaic systems that produce electricity for their own use or to feed the grid were not included in the balance sheet for reasons of comparability.

Table 2. $\mathrm{CO}_{2}$ equivalence factors $(\mathrm{kg} / \mathrm{kWhEnd})$.

\begin{tabular}{cc}
\hline Type of Energy & $\mathrm{CO}_{\mathbf{2}}$ Equivalence \\
\hline Electric Power & 0.617 \\
Natural Gas & 0.241 \\
Wooden Pellets & 0.018 \\
Co-Gen (Gas) & 0.196 \\
District Heating Erding & 0.192 \\
District Heating Göppingen & 0.230 \\
District Heating Ostfildern & 0.119 \\
\hline
\end{tabular}

The focus should be on the interaction between the building envelope and the systems technology. The third value for comparison, in addition to space energy demand and $\mathrm{CO}_{2}$ equivalence, makes it possible to consider the energy costs that are required to operate the building (heating, cooling, power supply, and artificial light). To simplify matters, we assumed a flat rate of 10 cents for every kilowatt hour of heat, and 20 cents for electricity. An economic energy analysis certainly shows a definite correlation with the "ecological value." Both the $\mathrm{CO}_{2}$ equivalence and the operational costs are based on the previously determined simulation results of the space energy demand. To evaluate visual comfort, we performed a dynamic daylight simulation using the Radiance and Daysim programs. This was done in Honeybee, a plug-in for the Grasshopper software. These programs determine the value (sDA = Spatial Daylight Autonomy) of the continuous daylight autonomy (cDA) and provide information on how much of the classroom is lit by sunlight to an illuminance of $500 \mathrm{Lux}$, as required by DIN EN 15251 [5]. In the case of school buildings, such as the Berufliche Oberschule Erding, which have an automatic sun protection system, the control system was implemented based on data from the planning office. For schools with manually controlled sun protection, such as the Wandermatte school system, the sun shade has been defined in the simulation to be closed by the user as soon as it is exposed to direct sunlight. Since the elementary school in Munich only has curtains, no sun protection was considered here.

\subsection{Survey Methodology}

In order to determine the subjective opinions of the schools' actual users, we conducted an anonymous survey of the pupils and teachers of the two classrooms where the measurements were carried out. The online survey was done on the SurveyMonkey online platform, where answers can be individually filtered and evaluated. Our process differed in Diedorf: there, our questions were integrated into a large-scale survey conducted by Augsburg University, and all the pupils at the Schmuttertal-Gymnasium were able to answer the questions. In total, eight of the twelve schools examined took part in the survey, the number of participants varies according to the number of pupils in each class. The results are shown in Figure 4. 


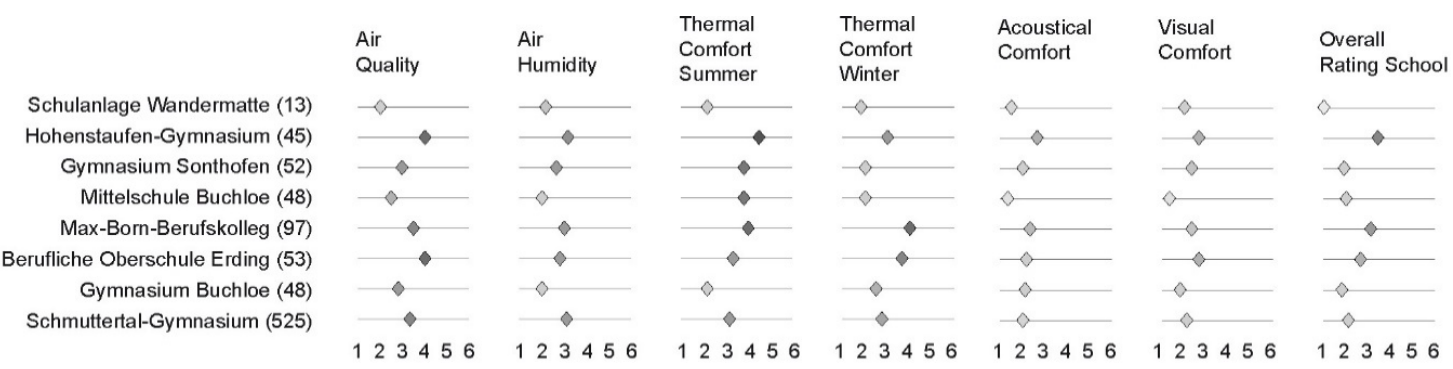

Figure 4. Number of participants of the survey and their average rating of different comfort parameters and an overall school rating according to school grades from 1 (very good) to 6 (insufficient).

\section{Results}

\subsection{Interior Comfort Results}

\subsubsection{Hygienic Comfort}

When we consider the $\mathrm{CO}_{2}$ concentration in relation to the outside temperature, all selected schools display a very good air quality in summer. Unlike the mechanically ventilated schools, the measured data of all naturally ventilated schools confirm research results of other studies [9], showing a high concentration of $\mathrm{CO}_{2}$ in the winter and thus having reduced air quality during that time. Due to drafts, the windows often remain closed during the winter, causing the $\mathrm{CO}_{2}$ concentration to increase over the course of the class period. Values of $3000 \mathrm{ppm}$ and higher were not uncommon, see Figure 5. We also saw that this was often not adequately "corrected" during the breaks because the rooms were insufficiently ventilated during that time. For example, over the course of the exemplary week in winter in the Schule im Scharnhauser Park in Ostfildern, the school's $\mathrm{CO}_{2}$ concentration shows that semi-intensive ventilation only happened during the lunch break. The tightness of the building envelope means that there is little air exchange during the night. For example, the $\mathrm{CO}_{2}$ concentration is already $1500 \mathrm{ppm}$ in the morning when classes start, meaning the threshold for good air has already been exceeded. This raises the question of whether it is enough to only offer openable windows in a naturally ventilated school. Obviously, one has to consider the strategy of natural ventilation in the design. This would include both clear instructions for the users and a certain basic ventilation system that utilizes either cross-ventilation or chimney ventilation. 


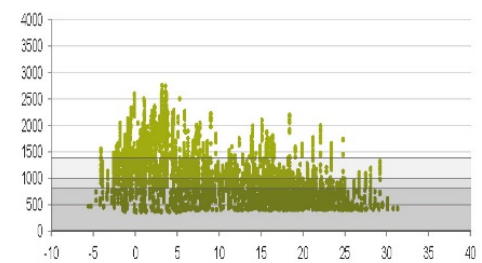

Grundschule an der Haimhauserstraße, Munich, 1898

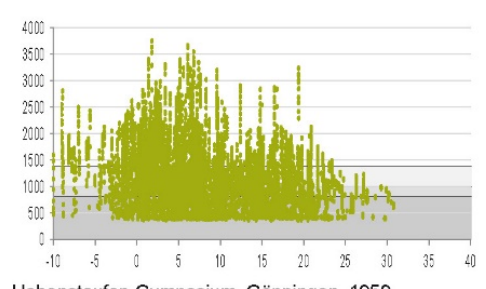

Hohenstaufen-Gymnasium, Göppingen, 1959

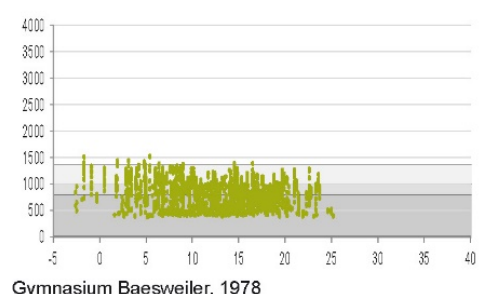

Gymnasium Baesweiler, 1978

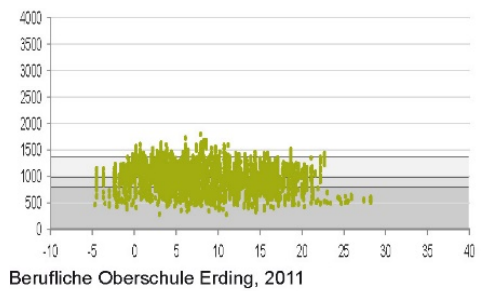

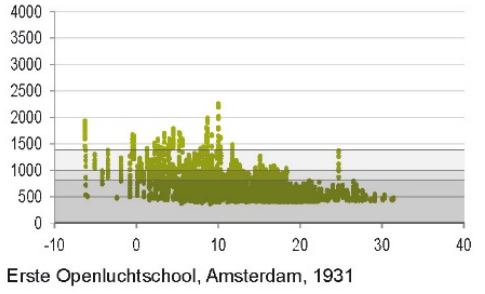

Erste Openluchtschool, Amsterdam, 1931

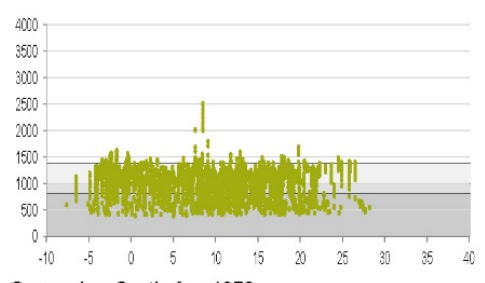

Gymnasium Sonthofen, 1976
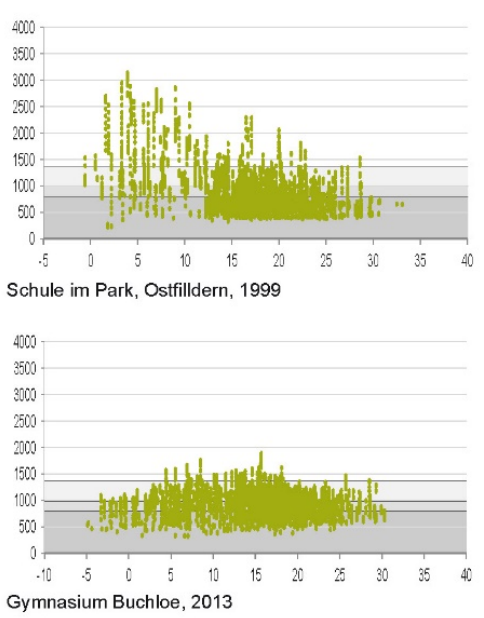
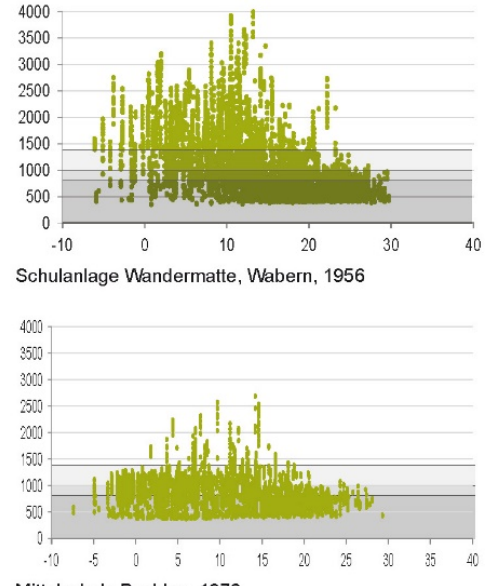

Mittelschule Buchloe, 1976

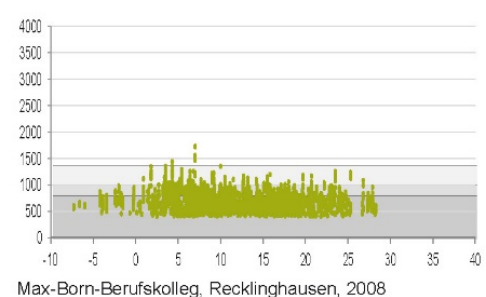

Max-Born-Berufskolleg. Recklinghausen, 2008

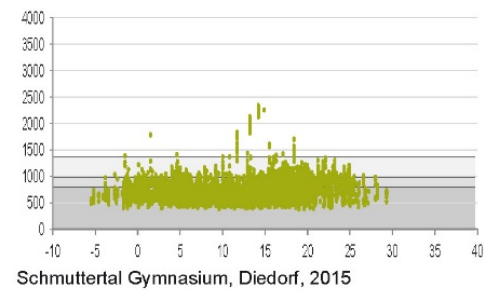

Figure 5. $\mathrm{CO}_{2}$ concentration (ppm) (y-axis) in relation to the outdoor temperature $\left({ }^{\circ} \mathrm{C}\right)(\mathrm{x}$-axis).

Our $\mathrm{CO}_{2}$ concentration frequency distribution graphs (Figure 6) show how many times thresholds are exceeded during periods of use. The four naturally ventilated schools show a significant difference between summer and winter. In the eight mechanically ventilated schools, the summer and winter curves are much closer together and all mechanically ventilated schools clearly have very good air quality. In the four naturally ventilated schools, a clear difference is apparent in the frequency distribution during the winter: while the $\mathrm{CO}_{2}$ concentration in the Munich school—built by Theodor Fischer-exceeded approximately $1500 \mathrm{ppm}$ a little over $20 \%$ of the time, it occurred nearly $30 \%$ of the time in Göppingen and almost $40 \%$ of the time in Ostfildern and Wabern. As expected, statistical comparison confirms the Munich school has a clear advantage due to its large volume of space. The somewhat better values in Göppingen-compared to the new school in Ostfildern and the renovated school in Wabern-are most likely due to the relatively leaky, unrenovated facade. Wabern and Ostfildern are representative of the kind of air quality that results from a technically modern-which is to say airtight-facade. It is interesting that an analysis of the questionnaires shows a different conclusion. On average, the mechanically ventilated schools scored relatively poorly in the subjective assessment. The Berufskolleg in Recklinghausen has no manually openable windows and, despite having very good measured air quality, it only received an average grade of 3.6 in the subjective survey. At the same time, the measurements in Wabern show very high $\mathrm{CO}_{2}$ concentrations, nevertheless, the users rated the air quality as good. Due to the subjective result of the survey, one must certainly question whether mechanical ventilation alone is ultimately the best option. 

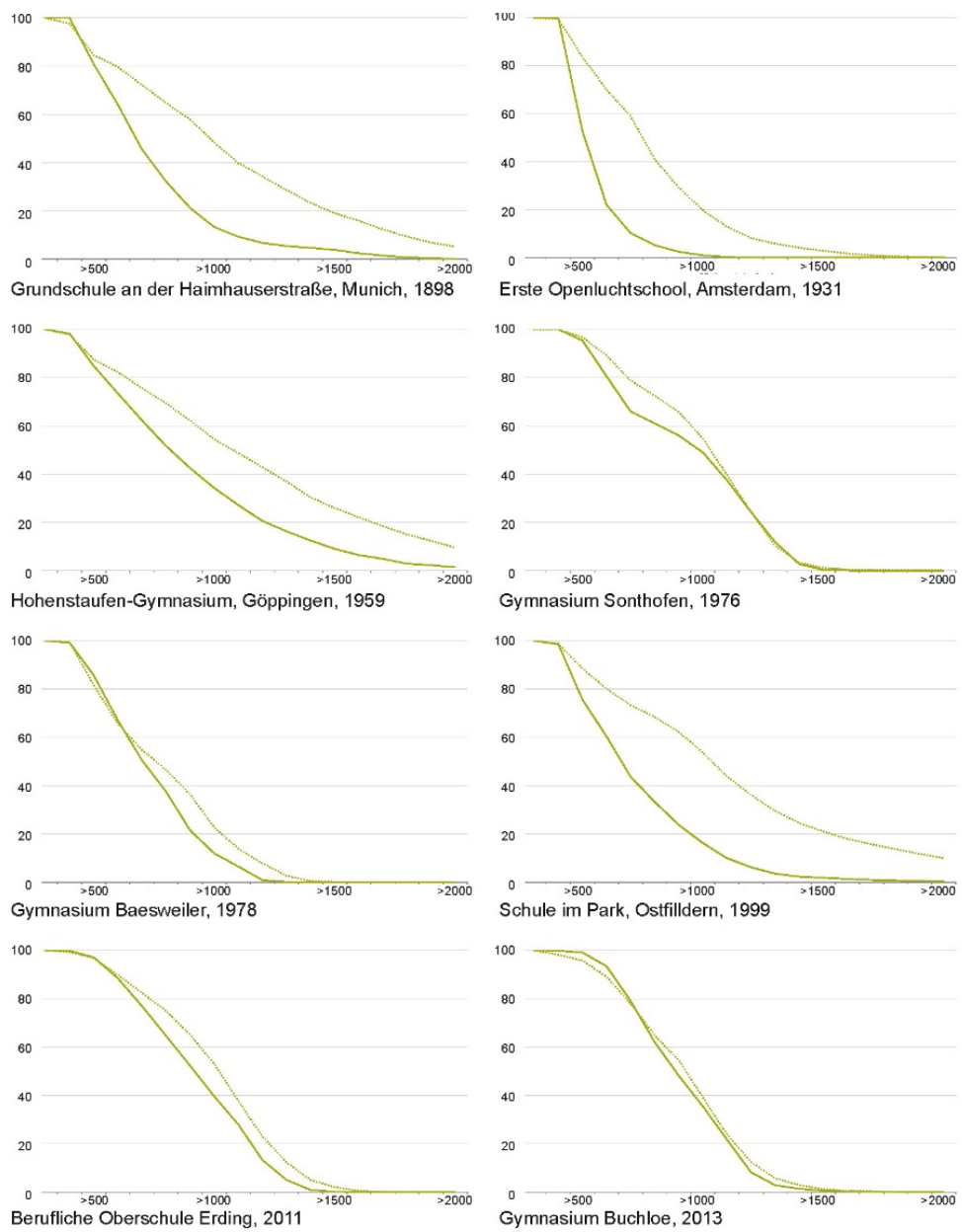

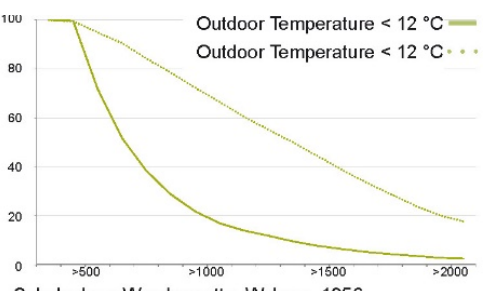

Schulanlage Wandermatte, Wabern, 1956

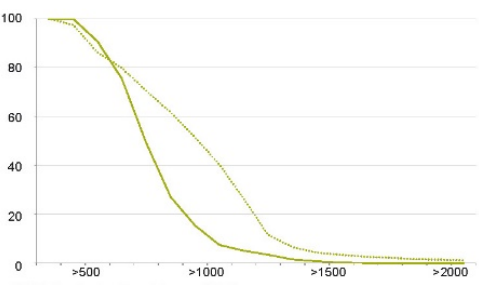

Mittelschule Buchloe, 1976
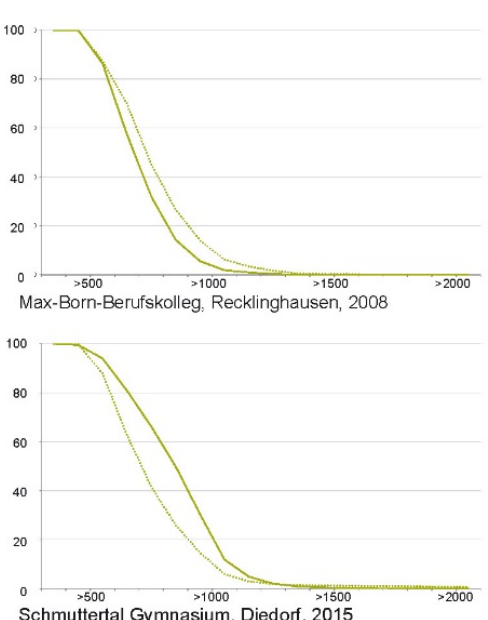

Figure 6. Frequency distribution (\%) (y-axis) in relation to $\mathrm{CO}_{2}$ concentration (ppm) (x-axis). Full line shows $>12{ }^{\circ} \mathrm{C}$, dotted line $<12{ }^{\circ} \mathrm{C}$ outdoor temperature.

\subsubsection{Thermal Comfort}

Regarding thermal comfort in the winter, in Figure 7, we see that sometimes temperatures did not reach the minimum temperature of $20^{\circ} \mathrm{C}$. This was particularly a problem in schools where the heating/cooling system is coupled to the thermal mass. This is particularly evident in the Max-Born-Kolleg in Recklinghausen, which demonstrates the control problems of slow-reacting heating systems in schools where heating occurs primarily by way of the concrete floor, using airflow-based thermo-active floor slabs. During seasonal transitions, it is especially necessary to heat the rooms in the morning. Due to both the heat dissipation coming from the students and from solar radiation, the rooms then threaten to overheat—even at moderate outdoor temperatures—due to the system's inertia. As a result, the rooms need to be cooled shortly afterwards. The winter comfort in Göppingen is very limited because the facade is still unrenovated and the radiators-after the heat supply was switched from steam to hot water-do not have the necessary heating capacity. In Amsterdam, the high percentage of glass occasionally leads to losses in comfort in winter. Summer overheating in some schools is due to a high percentage of glass in combination with inefficient sun protection. Examples of this are the schools in Amsterdam, where an interior curtain lets the solar load into the classroom, and Göppingen, where the previously installed Brise-Soleil sun protection no longer exists and many of the retrofitted outdoor shades no longer function. 

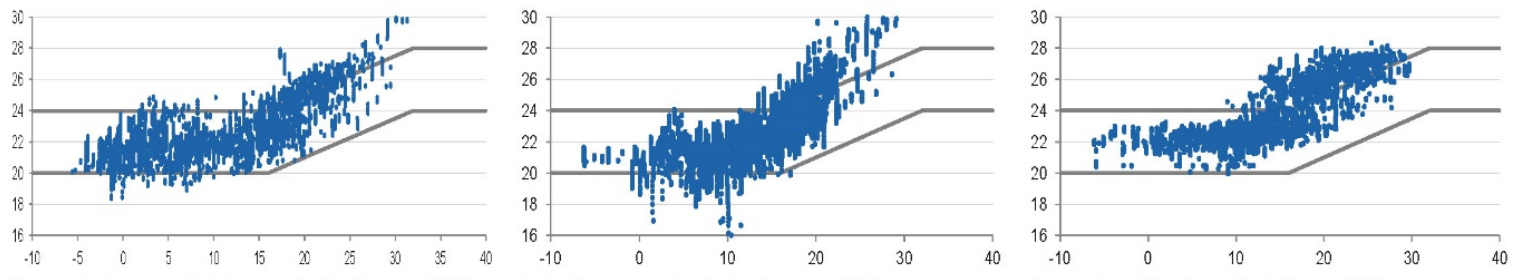

Grundschule an der Haimhauserstraße, Munich, 1898

Erste Openluchtschool, Amsterdam, 1931

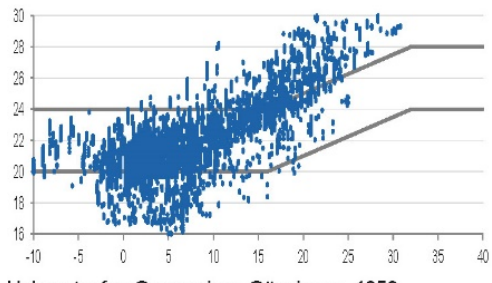

Hohenstaufen-Gymnasium, Göppingen, 1959

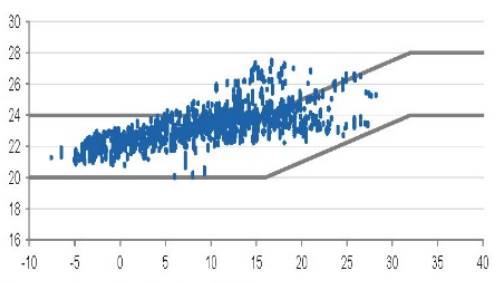

Gymnasium Sonthofen, 1976
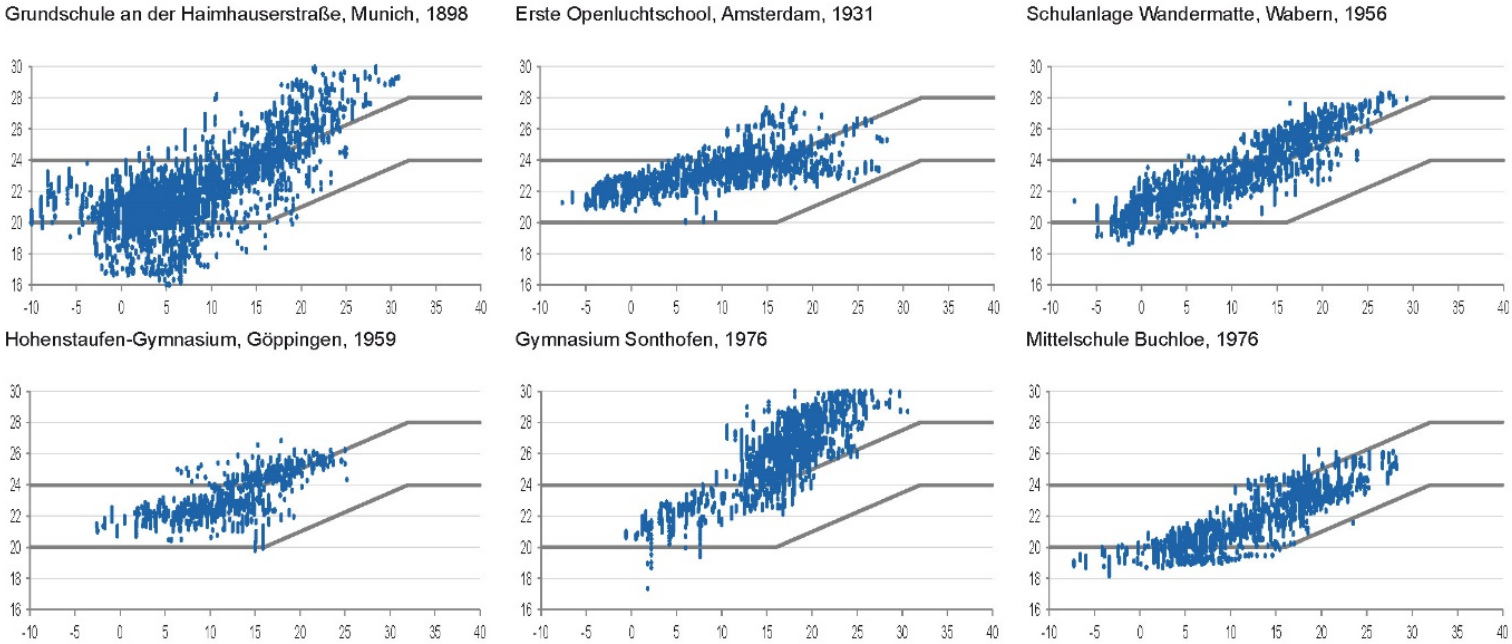

Gymnasium Baesweiler, 1978

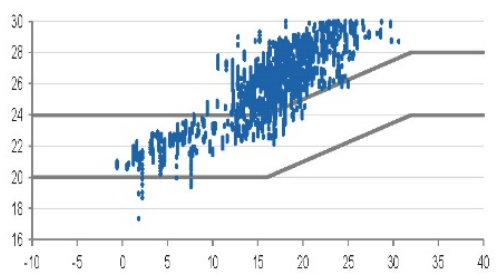

Schule im Park, Ostfilldern, 1999

Mittelschule Buchloe, 1976
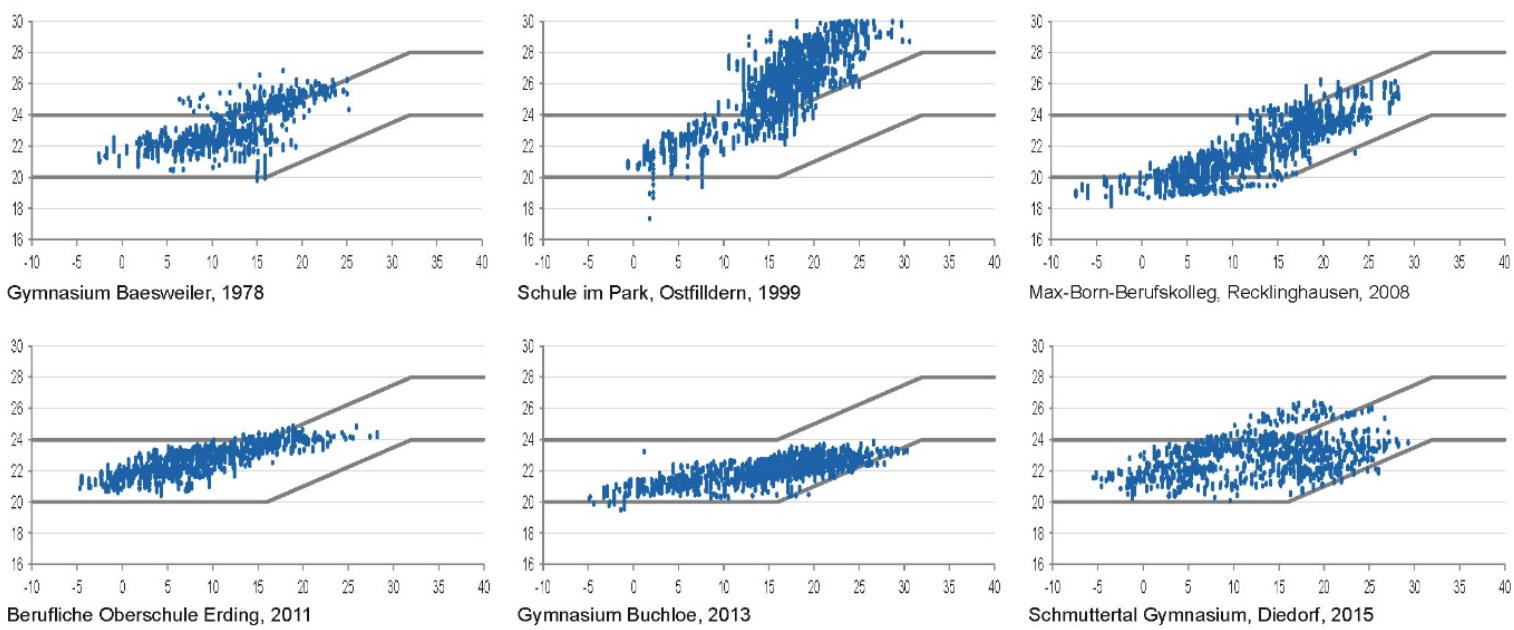

Max-Born-Berufskolleg, Recklinghausen, 2008

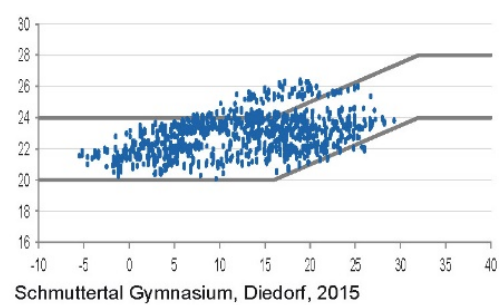

Figure 7. Indoor temperature $\left({ }^{\circ} \mathrm{C}\right)$ (y-axis) in relation to the outdoor temperature $\left({ }^{\circ} \mathrm{C}\right)(\mathrm{x}$-axis).

In Ostfildern, there is no night cooling by ventilation, which fails to capitalize on the building's thermal mass, and the external textile sun protection does not sufficiently keep out the solar loads. This means that the building overheats even when outside temperatures are moderate. In the schools without active cooling, the schools in Munich and Baesweiler show that simple measures can nevertheless be used to achieve good summer thermal protection. On the one hand, these can be passive measures, such as utilizing the thermal mass, installing a well-functioning external sun protection system-louvered blinds, ideally—or using mechanical ventilation for night cooling [10]. In Wabern, we saw that, during seasonal transition periods when the sun is low in the sky, room air temperatures already get up to $28^{\circ} \mathrm{C}$, which is due to the textile sunshade. When the summer sun is high, the room temperature does not increase any further. These examples demonstrate the importance of well-functioning external sun protection to prevent overheating.

Summer heat protection generally works very well in the schools that have mechanical cooling, either in the form of an air supply cooling system like in Erding, or cooling ceilings like Buchloe Gymnasium. Although the measured data at Buchloe Gymnasium show signs of undercooling as outside temperatures rise, in the student survey, it was rated the best by far compared to the other cooled schools. In the seasonal transition periods, some schools with a slow-reacting heating system exceed the maximum comfort temperature. Nevertheless, students and teachers only gave them a medium rating, often with the remark that it tends to be too warm (Recklinghausen, Erding, and Sonthofen). In Recklinghausen and Erding, the subjective perception can be attributed to the fact that the windows are not or are only partially openable. Research into so-called adaptive comfort standards clearly shows that users in naturally ventilated rooms accept a higher room temperature [11]. Increased winter air 
exchange leads to lower $\mathrm{CO}_{2}$ concentrations, but continuously introducing dry outside air reduces the humidity in the room. The naturally ventilated schools never fell below the recommended relative humidity of 30\% (Ostfildern and Wabern) or only slightly (Munich was never below 25\%), see Figure 8 . Göppingen had a low absolute humidity due to its leaky facade, but the relative humidity was mostly acceptable due to the very low air temperature. In contrast, schools with a mechanical ventilation system without moisture recovery often had an indoor humidity of less than $20 \%$ when the outdoor temperatures were cold. This can have an effect on the mucous membranes and can lead to dry mouths and dry eyes, which is especially uncomfortable for contact lens wearers [12]. An exception is the Berufliche Oberschule in Erding, where the relative humidity on cold days did not fall significantly below $30 \%$ due to heat and moisture recovery. Interestingly, however, on cooler days during the seasonal transition period, it had a relative humidity of about $20 \%$. This is because even at outside temperatures of 5 to $10{ }^{\circ} \mathrm{C}$, as soon as the sun is shining, the air temperature in the room rises to $24{ }^{\circ} \mathrm{C}$, which in turn lowers the relative humidity.
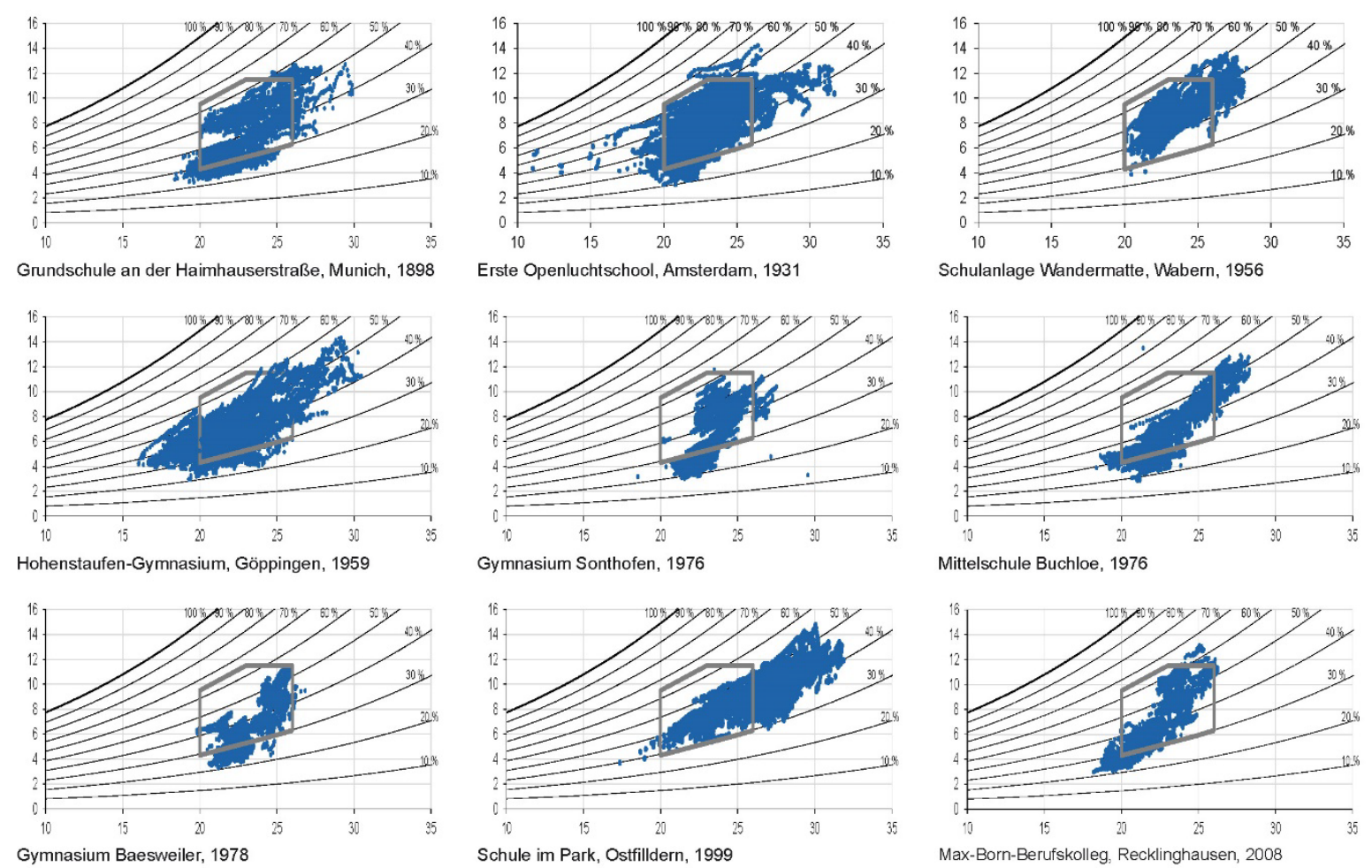

Mittelschule Buchloe, 1976
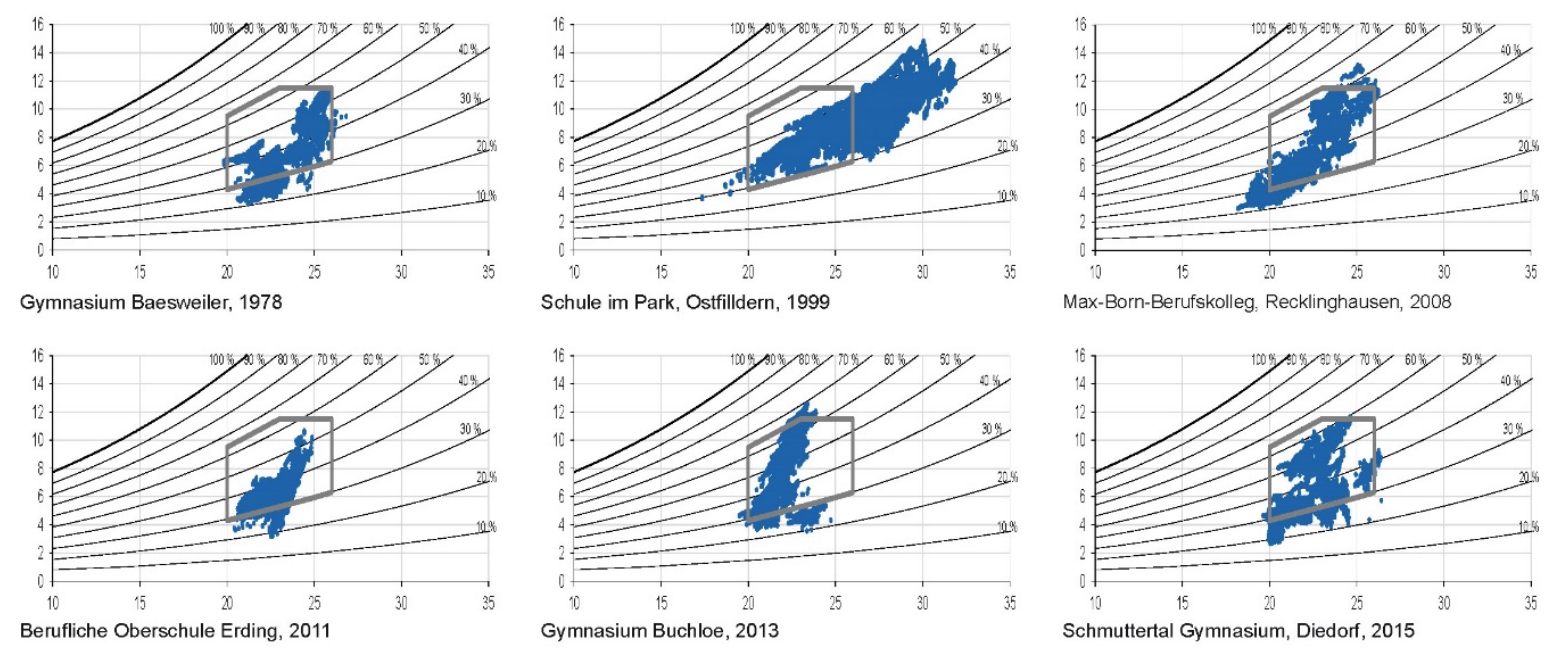

Figure 8. Psychometric chart, showing absolute humidity $(\mathrm{g} / \mathrm{kg})$ (y-axis) in relation to the outdoor temperature $\left({ }^{\circ} \mathrm{C}\right)$ (x-axis) and relative humidity $(\%)$ (curved lines).

\subsubsection{Acoustic Comfort}

Our measurements of the reverberation time in most schools show a good or very good acoustic comfort level (Figure 9). In a few schools, the comfort range was slightly exceeded at low frequencies. Various measures have been taken to improve the room acoustics: some of the ceilings are fully covered 
with acoustic absorbers, and in some schools, only some parts of the ceiling are covered to allow for thermal activation of the structural elements.
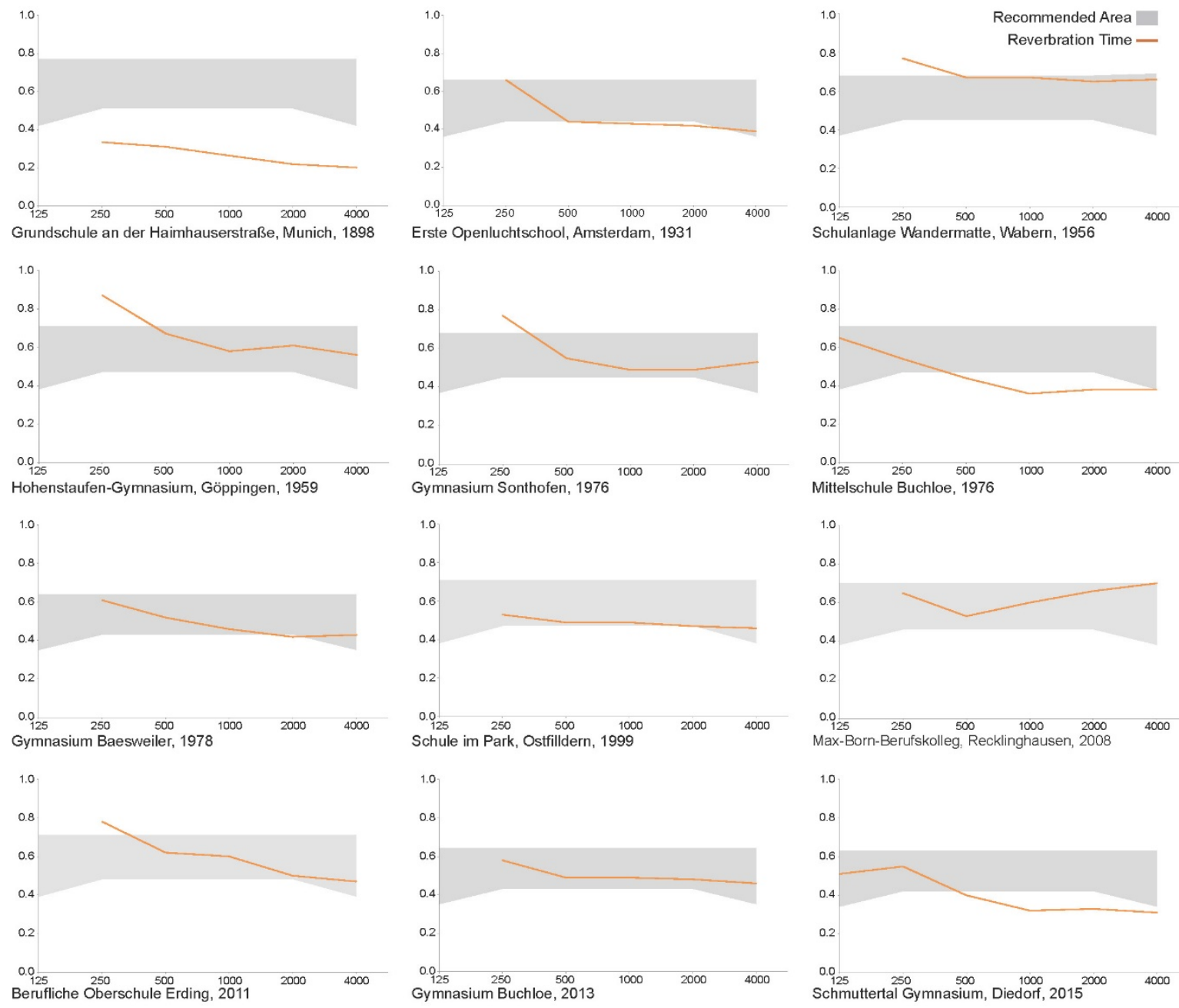

Figure 9. Reverberation time (s) (y-axis) in relation to the frequency (Hz) (x-axis).

In the area of acoustics, there was a very good correlation with the subjective results of the survey. In general, users rated daylight and acoustics as good.

\subsubsection{Visual Comfort}

As shown in Figure 10, all schools achieved good to very good results in the daylight simulation. Their window-to-wall ratio is $60 \%$ on average, with Munich having the minimum at just under $40 \%$ and Recklinghausen the maximum with $100 \%$ (see Appendix A). In general, a high window-to-wall ratio means an increase in solar radiation. The low winter sun usually reduces the heating demand of the rooms, but in the summer, there is the danger of overheating [13]. This mainly affects east- and west-facing rooms when the sun is low and hits the windows unhindered. Most schools respond to this situation with external louvered blinds. However, because the slats close tightly due to the angle of incidence, the view to the outside is reduced. Optimally, the blinds offer the option of a daylight function, where, in the closed position, the upper slats direct light to the ceiling when closed and thus provide daylight without glare. If this function is not available, it may be necessary to turn on artificial light. None of the schools had vertical sun protection for east- and west-facing rooms. South-facing rooms are easier to manage because here, horizontal louvered blinds work optimally. The slats do not close completely and provide a view outdoors. In some schools, such as Erding, the slats respond to 
the sun's course and change their angle of inclination. In almost all schools with external blinds, this angle is electrically controlled and is based on the amount of sun. In the survey, however, users did not often understand the control technology and accordingly felt "patronized" by it.

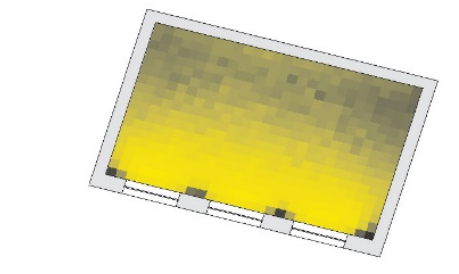

Grundschule an der Haimhauserstraße, Munich, 1898 SDA: $75.1 \%$

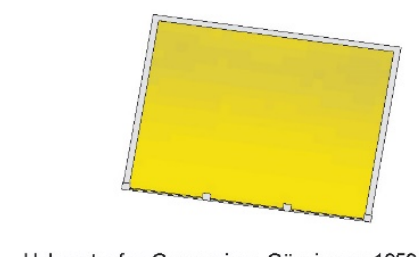

Hohenstaufen-Gymnasium, Göppingen, 1959 SDA: $100 \%$

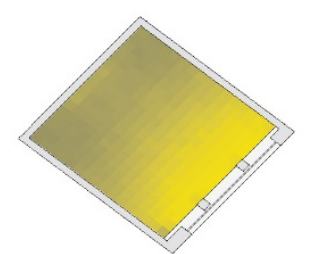

Gymnasium Baesweiler, 1978 SDA: $100 \%$

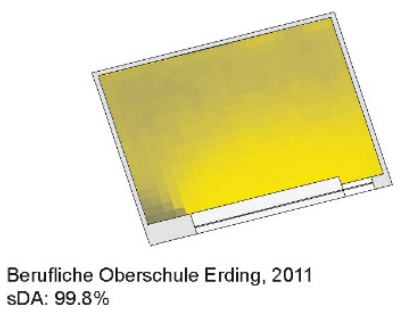

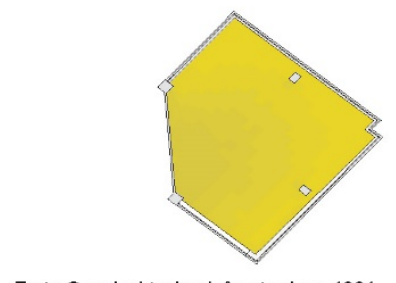

Erste Openluchtschool, Amsterdam, 1931 SDA: $100 \%$

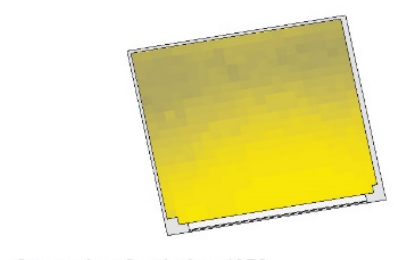

Gymnasium Sonthofen, 1976

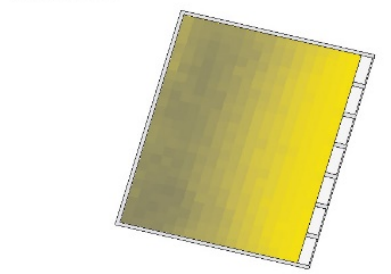

Schule im Park, Ostfilldern, 1999 sDA: $76.7 \%$

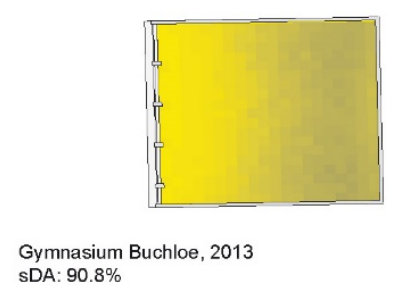

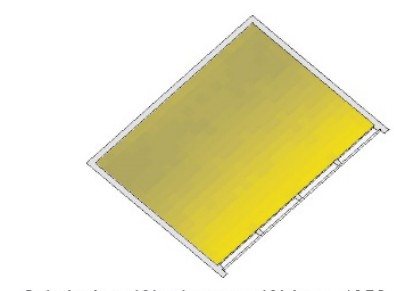

Schulanlage Wandermatte, Wabern, 1956 SDA: $100 \%$

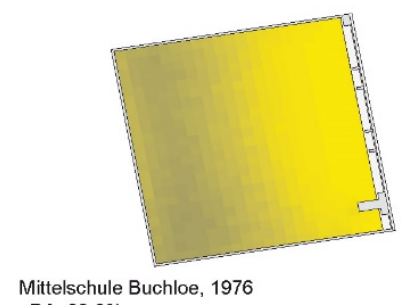

SDA: $99.3 \%$

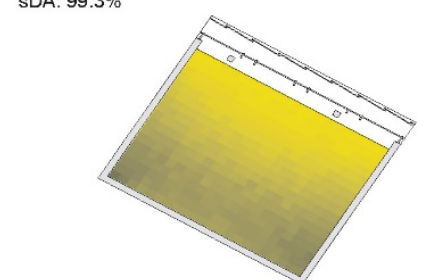

Max-Born-Berufskolleg, Recklinghausen, 2008 $\mathrm{SDA}: 83.6 \%$

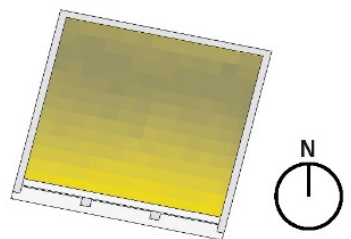

Schmuttertal Gymnasium, Diedorf, 2015 SDA: $96.5 \%$

Figure 10. Daylight simulation results in sDA (Spatial Daylight Autonomy).

When choosing sun protection, louvered blinds are generally preferable to a flat textile sun shade, which always requires a compromise between reducing solar gains and letting in daylight. The two schools in Wabern and Ostfildern have external, comprehensive textile sunshades. Here, we can see clear differences in the daylight simulation results. When the textile shades in the Schulanlage Wandermatte are drawn, they allow a sufficient amount of daylight into the room as diffused light and achieve a $100 \%$ daylight autonomy. However, the orange textile shade in Ostfildern darkens the interior because it lets in much less daylight (sDA: 76.7\%). At the same time, the more transparent shade at the Schulanlage Wandermatte does not meet the requirements for summer heat protection.

\subsection{Technology and Energy}

Overall, the mechanically ventilated schools with heat recovery systems show a shift in the energy demand from heat to electricity (Figures 11 and 12). Wabern had the lowest $\mathrm{CO}_{2}$ emissions due to its biomass furnace. From an energy point of view, it is necessary to pose a general question: does it make sense to use electricity to run a mechanical ventilation system-which reduces the heating demand-if it ends up emitting more $\mathrm{CO}_{2}$ to produce the electricity than is saved by heat recovery? An example of this is the school in Ostfildern. It does not have mechanical ventilation with heat recovery but does 
very well in terms of energy consumption because it is connected to a low- $\mathrm{CO}_{2}$ district heating system. This is even clearer at the school in Wabern: despite having an increased heat demand due to high transmission and ventilation heat losses, it has the lowest $\mathrm{CO}_{2}$ emissions of all twelve schools because of its biomass furnace.

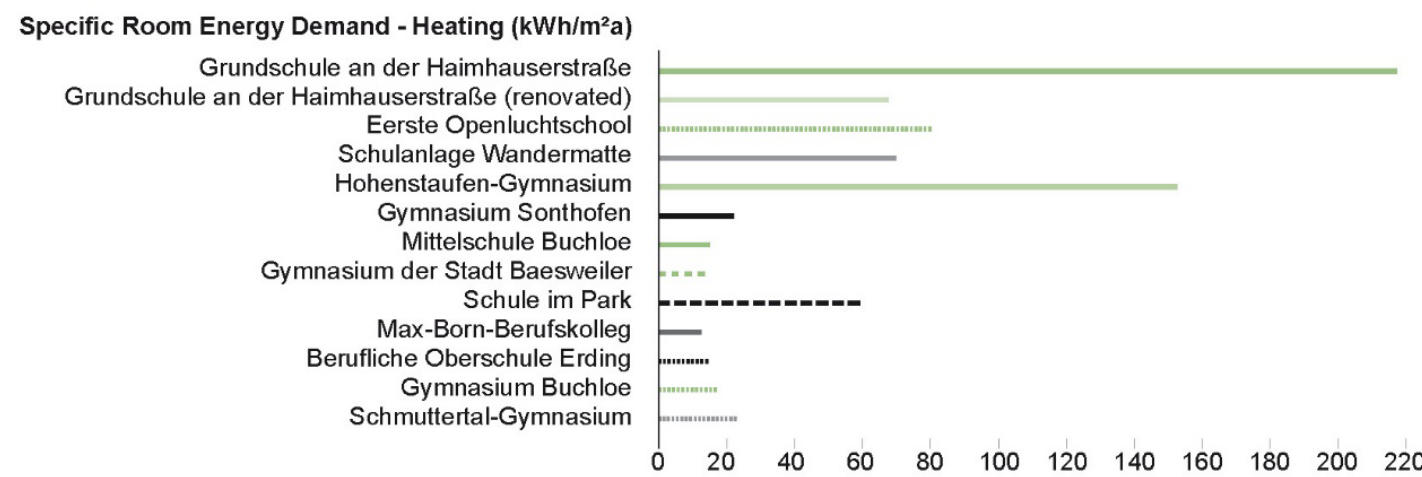

Specific Room Energy Demand - Cooling ( $\left.\mathrm{kWh} / \mathrm{m}^{2} \mathrm{a}\right)$

Gymnasium Sonthofen Max-Born-Berufskolleg Berufliche Oberschule Erding

Gymnasium Buchloe

Schmuttertal-Gymnasium

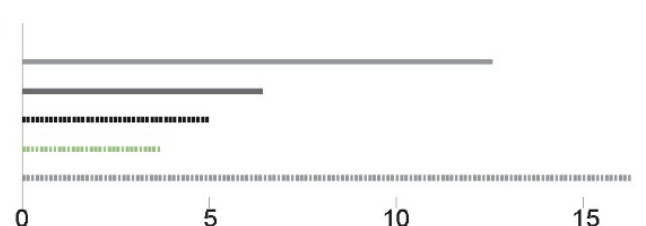

Specific Room Energy Demand - Auxiliary Energy (kWh/m²a)

Grundschule an der Haimhauserstraße Grundschule an der Haimhauserstraße (renovated) Eerste Openluchtschool Schulanlage Wandermatte Hohenstaufen-Gymnasium Gymnasium Sonthofen Mittelschule Buchloe Gymnasium der Stadt Baesweiler Schule im Park Max-Born-Berufskolleg Berufliche Oberschule Erding Gymnasium Buchloe Schmuttertal-Gymnasium

Specific Room Energy Demand - Lighting (kWh/m²a) 0
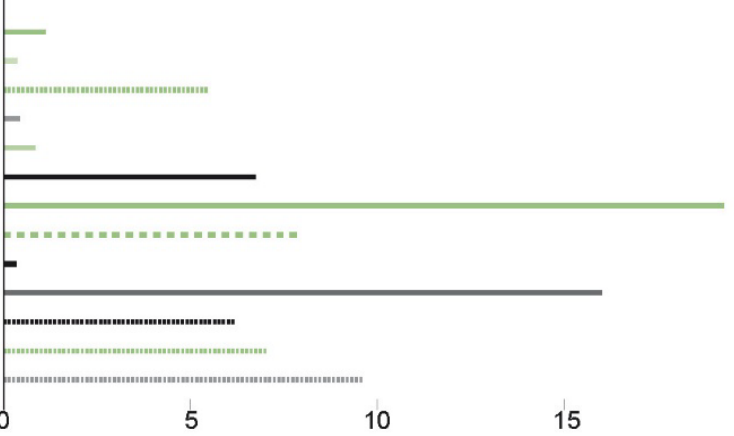

Grundschule an der Haimhauserstraße Grundschule an der Haimhauserstraße (renovated)

Eerste Openluchtschool Schulanlage Wandermatte Hohenstaufen-Gymnasium Gymnasium Sonthofen Mittelschule Buchloe Gymnasium der Stadt Baesweiler Max-Born-Berufskolleg Berufliche Oberschule Erding Gymnasium Buchloe Schmuttertal-Gymnasium

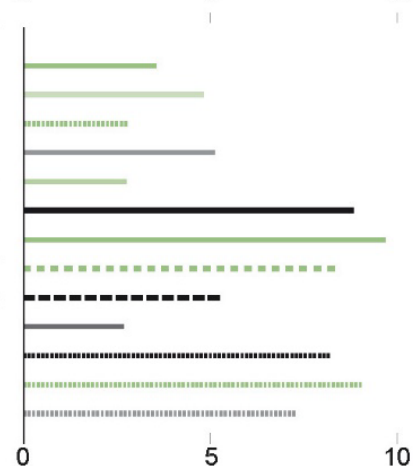

Figure 11. Simulation results of the energy demand for heating, cooling, auxiliary energy, and lighting. 


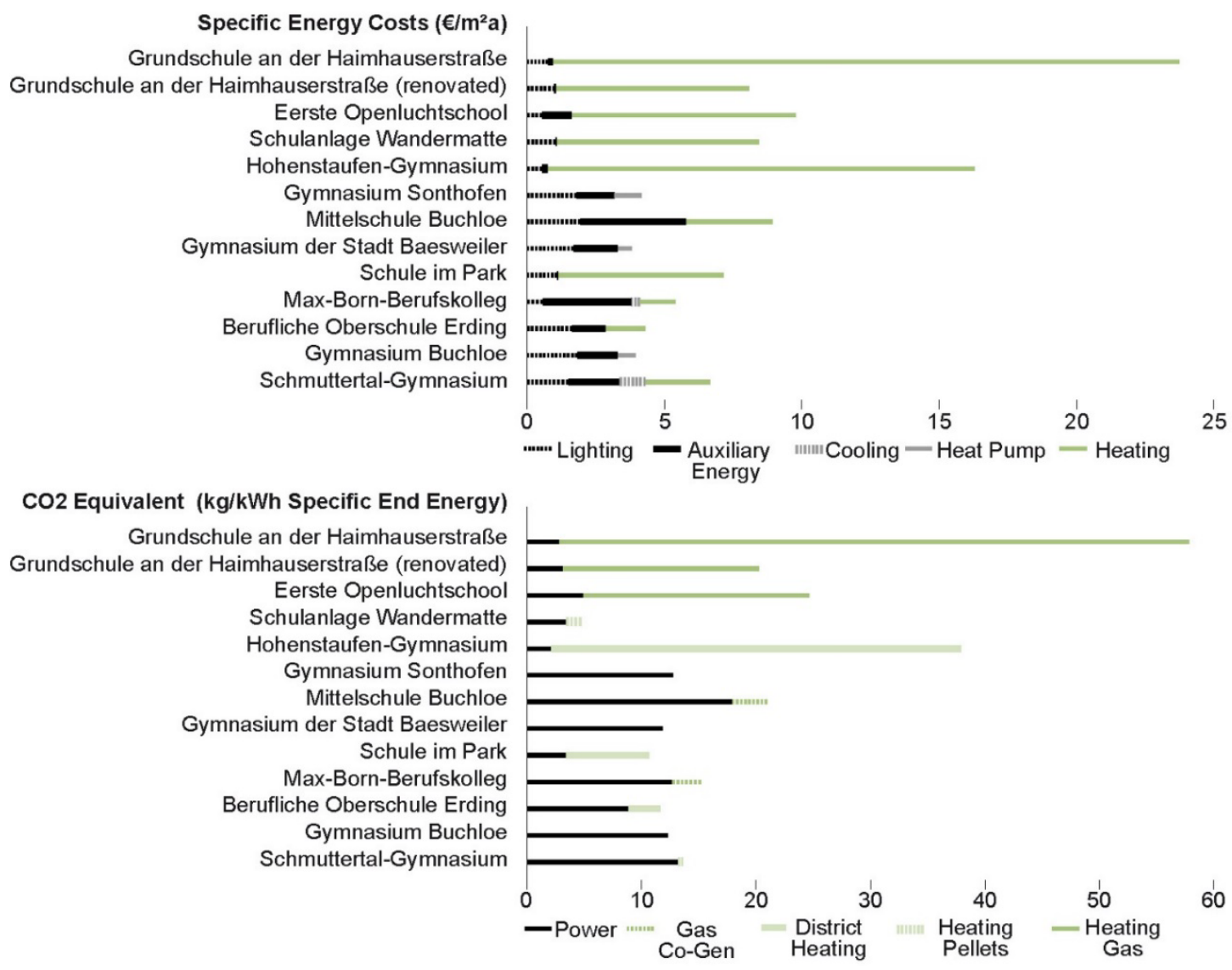

Figure 12. Simulation results for energy costs and $\mathrm{CO}_{2}$ equivalent emissions.

The very technologically modern schools like the Gymnasiums Buchloe in Diedorf, Erding, Baesweiler, and Sonthofen all show similar very good results in terms of low $\mathrm{CO}_{2}$ emissions. It is interesting that technologically demanding schools like those in Diedorf and Recklinghausen have $\mathrm{CO}_{2}$ equivalent emissions that are "only" about 30\% lower than the Theodor Fischer School in Munich-if the upcoming renovation is accounted for. This result is achieved without using mechanical ventilation with heat recovery, and with a still-uninsulated facade. Here is a comparison to illustrate the difference: this amount is similar to using a whiteboard as compared to using a desktop computer eight hours a day for 42 weeks a year, including standby losses.

Looking at the energy costs, the renovated school in Munich is even closer to the technologically modern and sophisticated schools. If one takes the schools in Munich and Göppingen out of the comparison (in their unrenovated states), it turns out that the energy costs to operate all the schools-regardless of the amount of technical equipment-are between approximately 4 and 8 euros per square meter annually.

As described in the methodology section, in the simulations designed to determine energy demands, we assumed an ideal user as well as an ideal MCR technology and also that the equipment is in perfect condition. We did not take into account things like increased pressure loss and the resultant increase in fan flow when the filters are not cleaned regularly, nor the fact that an ideal user does not exist. Thus, in reality, the power demand for artificial light will be greater in all schools. The heating demand in the naturally ventilated schools will also be lower due to insufficient ventilation-but at the expense of air quality. The energy demand of the technologically demanding schools will tend to be greater as well because experience has shown that MCR technology rarely works "optimally." As a result, the difference in energy demands between naturally ventilated and mechanically ventilated schools is further reduced. 


\section{Discussion}

\subsection{Ventilation Strategy}

The studies show that there is a discrepancy between objective measurement and subjective perception. Mechanically ventilated schools have objectively better air quality in terms of $\mathrm{CO}_{2}$ concentration, especially in winter. Nevertheless, subjective perception is often different. In addition, mechanical ventilation reduces the indoor humidity when there is no moisture recovery. This can be corrected by humidifying the air, but then there is a risk of germ contamination, and it requires careful monitoring and maintenance. If this maintenance is not done or is not done sufficiently, the germs are distributed throughout the building through the ventilation system [14]. Knowing the condition of many schools, this method is certainly not recommended. A reasonable and pragmatic solution would be to reduce the amount of fresh air on cold days and combine it with natural purge ventilation during break times. In addition, the use of heat and moisture recovery is recommended. It should be noted that the Theodor Fischer School in Munich, with its larger rooms and a ceiling height of $4 \mathrm{~m}$, performed best out of all the naturally ventilated schools. Volume helps! This will be further improved if, after the renovation, the old and currently inactive exhaust ducts are put back into operation, which will increase the air exchange. It can also be seen that a purely mechanical ventilation system-in the worst case, without openable windows-was rejected by the users, who judged the air quality in such situations to be bad.

There is also the general topic of maintenance and servicing. The more technologically complex the equipment is, the greater the cost involved. The air distribution system must be kept in a perfectly hygienic condition. This includes, among other things, cleaning the filters regularly, so that the mechanical ventilation actually improves the air quality and consumes as little power as possible [15]. The proper functioning of the system technology must be constantly monitored and ensured. Fire dampers can shut down, actuators can fail, etc. This leads to ongoing costs that must be paid to maintain air quality and avoid system deterioration.

Ultimately, it can be said that both mechanical ventilation and natural ventilation are possible; however, for the reasons mentioned above, mechanical ventilation should be combined with natural ventilation for so-called hybrid ventilation. When working out the dimensions of the mechanical ventilation system, purge ventilation during breaks must be considered, which can almost halve the amount of air (about $15 \mathrm{~m}^{3} / \mathrm{h}$ per pupil). Such a reduced amount of air calls into question the investment into individual room controls, as is used in Diedorf, for example. There, sensors regulate $\mathrm{CO}_{2}$ and the amount of air for each individual room. From an energetic point of view, this is just as welcome as the fact that this is being tested in a pilot school like in Diedorf. Nevertheless, there is still the question of whether this approach is transferable to other schools. Is the financial burden justified, and is it possible to ensure the necessary maintenance and servicing cycles, so that the system will still function flawlessly in 10 or 20 years? It would be technologically easier to mechanically ventilate all the rooms during the main instruction periods, for example. Moreover, there could be mechanical ventilation during the less busy afternoon hours, but only in particular wings of the building. If other rooms are occupied, they can still be ventilated through the windows, as is still common in schools.

Then again, the results of the measurements in the naturally ventilated schools show that natural ventilation must also be planned. The example of Ostfildern shows that it is not enough to merely provide openable windows. It is necessary to create a controlled "leak" in combination with a method of warming of the cold outside air near the facade and creating a natural flow of air. To achieve this, it is possible to use cross-ventilation that takes advantage of wind pressure or to use a chimney's stack effect, as was originally planned in the Theodor Fischer School in Munich. Of course, the decision regarding natural or mechanical ventilation must also take into account context parameters: for example, if the local air quality is bad or if there is increased noise from a busy street. 


\subsection{Thermal Comfort}

Regarding thermal comfort, the measurements show that summer heat protection is almost the most important, but also that it is possible to have reasonable summer heat protection, at least in normal classrooms, even without mechanical cooling. For this, it is important to have a good compromise between the amount of acoustically active surfaces and exposed thermal mass [10]. Several schools show that it is possible to achieve good acoustic comfort with about $30 \%$ of the ceiling devoted to acoustically active materials, in tandem with other measures. With regard to the thermal mass, however, the more the better. Nevertheless, it is not necessary to have $80 \mathrm{~cm}$ thick outer walls, as is the case in Munich. The thermal mass is most effective when the heat stored during the day is released from the components through effective ventilation at night. Schools such as the Berufliche Oberschule Erding are successfully implementing this using mechanically assisted nighttime cooling, but the ventilation system, again, needs electricity to achieve this-natural cross-ventilation or stack ventilation by a chimney would be optimal.

It is also absolutely necessary to effectively control solar heat gains via external sun protection. When using flat, textile curtains, a textile with a solar transmission below $5 \%$ should be chosen. However, such fabric is usually opaque and significantly reduces daylight usage when closed.

If a geothermal heat generator is installed, the cooling potential of the ground should be used in summer without mechanical cooling to improve the thermal comfort.

\subsection{Technical Systems}

When using technical systems, it is crucially important to scrutinize their appropriateness and robustness. As an example of appropriateness: if one compares the technology control centers of the schools in Munich and Diedorf, then one must inevitably ask the question of whether it is appropriate to reduce classroom volumes under the pressure of economic constraints, when, at the same time, the technology control centers are growing in volume every year. As an example of robustness: the school in Göppingen has not been renovated in almost 60 years and the Theodor Fischer school in Munich has only been renovated once in 120 years. In both schools, conditions have worsened over the years. In Göppingen, for example, the external, fixed sun protection was removed, and the cross-ventilation was closed off, and in Munich, the chimney was filled in. This is not an exception, but the rule, and it means that the systems and strategies employed must be low-maintenance, robust, and appropriate. Technical systems are basically an Achilles heel in terms of functional robustness. On the one hand, operating a building requires good maintenance and repair. On the other hand, the systems have a much lower service life than the building. Above all, MCR technology is based on hardware that, after only a few years, no longer corresponds to the state-of-the-art, and needed components are no longer available.

Author Contributions: All authors conceived and designed the experiments; all authors performed the experiments and analyzed the data; all authors have written, reviewed, and approved the final manuscript. All authors have read and agreed to the published version of the manuscript.

Funding: The research was funded by Deutsche Bundesstiftung Umwelt, Az: 332742/01. This work was supported by the German Research Foundation (DFG) and the Technical University of Munich within the funding programme, Open Access Publishing.

Conflicts of Interest: The authors declare no conflict of interest. The funders had no role in the design of the study; in the collection, analyses, or interpretation of data; in the writing of the manuscript, or in the decision to publish the results. 


\section{Appendix A}

Table A1. Overview construction.

\begin{tabular}{|c|c|c|c|c|c|}
\hline Name of the School & Location & $\begin{array}{l}\text { Year Construction/ } \\
\text { Renovation }\end{array}$ & $\begin{array}{l}\text { U-Value Wall/ } \\
\text { Window/Roof }\end{array}$ & $\begin{array}{c}\text { Window/ } \\
\text { Wall-Ratio }\end{array}$ & $\begin{array}{l}\text { Size/Volume } \\
\text { Classroom }\end{array}$ \\
\hline $\begin{array}{c}\text { Grundschule an der } \\
\text { Haimhauserstr. }\end{array}$ & Munich, Germany & 1898/2017-2018 & $0.9 / 1.4 / 2.2$ & $40 \%$ & $\begin{array}{l}82.3 \mathrm{~m}^{2} / \\
327.2 \mathrm{~m}^{3}\end{array}$ \\
\hline Eerste Openluchtschool & $\begin{array}{l}\text { Amsterdam, } \\
\text { Netherlands }\end{array}$ & 1927-1930/2010 & $0.73 / 1.27 / 0.48$ & $68 \%$ & $\begin{array}{l}55.6 \mathrm{~m}^{2} / \\
185.2 \mathrm{~m}^{3}\end{array}$ \\
\hline $\begin{array}{l}\text { Schulanlage } \\
\text { Wandermatte }\end{array}$ & $\begin{array}{l}\text { Wabern bei Bern, } \\
\text { Switzerland }\end{array}$ & 1955-1956/2015 & $0.84 / 0.75 / 0.34$ & $53 \%$ & $\begin{array}{r}62.3 \mathrm{~m}^{2} / \\
187.7 \mathrm{~m}^{3}\end{array}$ \\
\hline $\begin{array}{l}\text { Hohenstaufen- } \\
\text { Gymnasium }\end{array}$ & $\begin{array}{l}\text { Göppingen, } \\
\text { Germany }\end{array}$ & 1957-1959 & $1.44 / 0.76 / 0.81$ & $63 \%$ & $\begin{array}{l}67.0 \mathrm{~m}^{2} / \\
226.1 \mathrm{~m}^{3}\end{array}$ \\
\hline Gymnasium Sonthofen & Sonthofen, Germany & 1973-1974/2009-2011 & $0.15 / 0.86 / 0.14$ & $53 \%$ & $\begin{array}{l}70.4 \mathrm{~m}^{2} / \\
217.6 \mathrm{~m}^{3}\end{array}$ \\
\hline Mittelschule Buchloe & Buchloe, Germany & $\begin{array}{l}1974-1976 / \\
2010-2011\end{array}$ & $0.12 / 0.7 / 0.12$ & $61 \%$ & $\begin{array}{l}82.8 \mathrm{~m}^{2} / \\
250.3 \mathrm{~m}^{3}\end{array}$ \\
\hline $\begin{array}{c}\text { Gymnasium der Stadt } \\
\text { Baesweiler }\end{array}$ & Baesweiler, Germany & 1970-1978/2009-2014 & $0.1 / 0.7 / 0.1$ & $59 \%$ & $\begin{array}{l}49.6 \mathrm{~m}^{2} / \\
162.6 \mathrm{~m}^{2}\end{array}$ \\
\hline $\begin{array}{c}\text { Schule } \\
\text { im Park }\end{array}$ & Ostfildern, Germany & 1996-2002 & $0.27 / 1.4 / 0.16$ & $55 \%$ & $\begin{array}{l}66.3 \mathrm{~m}^{2} / \\
231.8 \mathrm{~m}^{3}\end{array}$ \\
\hline Max-Born-Berufskolleg & $\begin{array}{l}\text { Reckling-hausen, } \\
\text { Germany }\end{array}$ & 2005-2008 & $0.72 / 1.27 / 0.18$ & $100 \%$ & $\begin{array}{l}70.0 \mathrm{~m}^{2} / \\
206.8 \mathrm{~m}^{3}\end{array}$ \\
\hline $\begin{array}{c}\text { Berufliche Oberschule } \\
\text { Erding }\end{array}$ & Erding, Germany & 2009-2011 & $0.13 / 0.7 / 0.1$ & $60 \%$ & $\begin{array}{l}74.6 \mathrm{~m}^{2} / \\
233.6 \mathrm{~m}^{3}\end{array}$ \\
\hline Gymnasium Buchloe & Buchloe, Germany & $2012-2013$ & $0.12 / 0.7 / 0.09$ & $68 \%$ & $\begin{array}{l}66.1 \mathrm{~m}^{2} / \\
231.4 \mathrm{~m}^{3}\end{array}$ \\
\hline Schmuttertal-Gymnasium & Diedorf, Germany & 2013-2015 & $0.12 / 0.7 / 0.15$ & $58 \%$ & $\begin{array}{l}61.6 \mathrm{~m}^{2} / \\
198.0 \mathrm{~m}^{3}\end{array}$ \\
\hline
\end{tabular}

\section{References}

1. Zinner, M. SchulRAUMkultur. Wie Anstalten Loslassen? Wie in Schulen heimkommen? In Zeitschrift Ästhetische Bildung; 2014; p. 12. Available online: http://www.schulraumkultur.at/perch/resources/ 140806-blog-zinner.michael-2014artikel.zaebjg6.20141-loslassenheimkommen-seite1bis17.pdf (accessed on 3 February 2020).

2. Sarbu, I.; Sebarchievici, C. Cpects of indoor environmental quality assessment in buildings. Energy Build. 2013, 60, 410-419. [CrossRef]

3. Jain, N.; Burman, E.; Robertson, C.; Stamp, S.; Shrubsole, C.; Aletta, F.; Barrett, E.; Oberman, T.; Kang, J.; Raynham, P. Building performance evaluation: Balancing energy and indoor environmental quality in a UK school building. Build. Serv. Eng. Res. Technol. 2019. [CrossRef]

4. DIN EN 13779. Lüftung von Nichtwohngebäuden-Allgemeine Grundlagen und Anforderungen für Lüftungs-und Klimaanlagen und Raumkühlsysteme. 2007. Available online: https://www.beuth.de/de/ norm/din-en-13779/94054008 (accessed on 3 February 2020).

5. DIN 15251. Eingangsparameter für das Raumklima zur Auslegung und Bewertung der Energieeffizienz von Gebäuden-Raumluftqualität, Temperatur, Licht und Akustik. 2007. Available online: https://www.beuth. de/de/norm/din-en-15251/155677389 (accessed on 3 February 2020).

6. DIN 1946-6. Raumlufttechnik-Teil 6: Lüftung von Wohnungen-Allgemeine Anforderungen, Anforderungen zur Bemessung, Ausführung und Kennzeichnung, Übergabe/Übernahme (Abnahme) und Instandhaltung. 2009. Available online: https://www.beuth.de/de/norm/din-1946-6/314483915 (accessed on 3 February 2020).

7. DIN 18041. Hörsamkeit in Räumen-Anforderungen, Empfehlungen und Hinweise für die Planung. 2004. Available online: https://www.beuth.de/de/norm/din-18041/245356770 (accessed on 3 February 2020).

8. Globales Emissions-Modell Integrierter Systeme (GEMIS). Hessisches Ministerium für Umwelt, Energie und Bundesangelegenheiten unter Mitarbeit des Öko-Institut; Version 4.93; IINAS: Darmstadt, Germany, 2014.

9. Fernández-Agüera, J.; Campano, M.Á.; Domínguez-Amarillo, S.; Acosta, I.; Sendra, J.J. CO $\mathrm{CO}_{2}$-Concentration and Occupant's Symptoms in Naturally Ventilated Schools in Mediterranean Climate. Buildings 2019, 9, 197. [CrossRef]

10. Hausladen, G.; de Saldanha, M.; Liedl, P.; Sager, C. Climate Design: Solutions for Buildings that Can Do More with Less Energy; Birkhäuser Architecture: Munich, Germany, 2005; ISBN 978-3764372446. 
11. de Dear, R.; Brager, G. Thermal comfort in naturally ventilated buildings: Revisons to ASHRAE Standard 55. Energy Build. 2002, 34, 549-561. [CrossRef]

12. Wolkoff, P. Indoor air humidity, air quality, and health-An overview. Int. J. Hyg. Environ. Health 2018, 221, 376-390. [CrossRef] [PubMed]

13. Chiesa, G.; Acquaviva, A.; Grosso, M.; Bottaccioli, L.; Floridia, M.; Pristeri, E.; Sanna, E.M. Parametric Optimization of Window-to Wall Ratio for Passive Building Adopting A Scripting Mehodology to Dynamic-Energy Simulation. Sustainability 2019, 11, 3078. [CrossRef]

14. Angelon-Gaetz, K.; Richardson, D.; Marshall, S.; Hernandez, M. Exploration of the effects of classroom humidity levels on teachers' respiratory symptoms. Int. Arch. Occup. Environ. Health 2016, 89, 729-737. [CrossRef] [PubMed]

15. Lüften in Schulen. Bessere Lernbedingungen für junge Menschen. In Themeninfo I/2015 Energieforschung Kompakt. BINE Informationsdienst; FIZ Karlsruhe-Leibnitz Institut für Informationsinfrastruktur GmbH: Eggenstein-Leopoldshafen, Germany, 2015; ISSN 1610-8302.

(C) 2020 by the authors. Licensee MDPI, Basel, Switzerland. This article is an open access article distributed under the terms and conditions of the Creative Commons Attribution (CC BY) license (http://creativecommons.org/licenses/by/4.0/). 